\title{
Migration rate and genetic diversity of two Drosophila maculifrons (Duda, 1927) populations from Highland Araucaria Forest Fragments in Southern Brazil
}

\author{
Silva, DC. ${ }^{a}$, Machado, $L P B .^{a}$ and Mateus, $R P^{a *}$ \\ aPrograma de Pós-Graduação em Biologia Evolutiva, Universidade Estadual do Centro-Oeste - UNICENTRO, \\ Rua Simeão Camargo Varela de Sá, 3, CEP 85040-080, Guarapuava, PR, Brazil \\ *e-mail: rogeriopmateus@gmail.com
}

Received: May 26, 2014 - Accepted: June 30, 2014 - Distributed: March 31, 2015

Flies from the Drosophilidae family have been suggested as appropriated for the assessment of the effects of habitat fragmentation (e.g., Mata et al., 2010). Cavasini et al. (2014) evaluated the Drosophilidae assemblages of Araucaria Forest fragments in Guarapuava/PR (southern of Brazil), including one studied here. They concluded that the areas are in intermediate state of conservation, and the size of the preserved area and/or connection with other fragments are important and should be considered for the establishment of conservation units. In this context, we analyzed the genetic variability of $D$. maculifrons (Duda, 1927), a forest dwelling species that belongs to the guaramunu group, collected in two conservation units of highland Araucaria Forest fragments in Guarapuava/ $\mathrm{PR}$, in order to establish parameters of genetic diversity and levels of gene flow. Thus, we expect to obtain insights about the connectivity level and its importance to conservation.

The two areas (Parque Municipal das Araucárias PMA: $25^{\circ} 23^{\prime} 36^{\prime}$ S, $51^{\circ} 27^{\prime} 19^{\prime \prime} \mathrm{W}$, with 43 ha; Parque Municipal São Francisco da Esperança-SSF: $25^{\circ} 03^{\prime}$ 52 " S, 51 17 ' 37 " W, with 84,7 ha) are located 36 kilometers apart from each other and at about $1,100 \mathrm{~m}$ above the sea level. The genetic variability was analyzed using nine allozymatic (Est, Gpdh, Idh, Me, Pgm, Hk, Mdh-1, Mdh-2 and Mdh-3 - Mateus and Sene, 2003) and nine microsatellite loci (034, 053, 057, 087, 095, 096, 099, 102 and 118 - Laborda et al., 2009). For allozyme data, the parameter $\Theta$ and migration rates $M$ were inferred through the MIGRATE-n v3.6.4 software (Beerli, 2012). Assuming an average mutation rate of $1.28 \times 10^{-6}$ per locus per generation (Voelker et al., 1980), average $\Theta$ estimates were translated to estimates of average effective population sizes (i.e. $\mathrm{Ne}=\Theta / 4 \mu$ ) for each population.

The allozymatic genetic diversities (Ho) for both populations (Table 1) were lower than those found by Saavedra et al. (1995) for D. maculifrons (0.2831) in the Rio Grande do Sul state, Brazil. They were also lower than those found by Machado et al. (2012) for D. ornatifrons (Duda, 1927), a closely related species of D. maculifrons, collected in the same areas (PMA -0.3609 ; SSF -0.4060$)$. It is noteworthy that, for allozymes, D. maculifrons and D. ornatifrons of SSF showed higher genetic diversity. For microsatellites, the Ho values obtained (Table 1) were lower than those found by Heinz (2012) for D. mediopunctata (Dobzhansky and Pavan, 1943), a closely related species of the tripunctata group, in two areas of Guarapuava/PR, PMA (0.5385) and Fazenda Brandalise (0.5062).

For allozymes, the genetic distance indexes resulted in a low to moderate differentiation between PMA and SSF (Nei's $D=0.0248$; Fst $=0.0556$ ). Low genetic differentiation for $D$. maculifrons was also recently detected for COI and COII mitochondrial genes (Cenzi de Ré et al., 2014). On the other hand, for microsatellites, low genetic differentiation was not observed $(D=0.4174$; Fst $=0.0901)$, probably because of its high variability. Therefore, despite the two populations are somewhat genetically similar (see Table 1), they depict some degree of differentiation. This is corroborated by PMA showing one locus less than SSF for both markers, and both populations presented several exclusive alleles (PMA: allozymes - 5; microsatellites - 13; SSF: allozymes - 3; microsatellites - 33).

The migration rates and population size estimations showed that SSF supplies much more migrants to PMA than otherwise $\left(\mathrm{M}_{\mathrm{SSF} \rightarrow \mathrm{PMA}}=2,160 ; \mathrm{M}_{\mathrm{PMA} \rightarrow \mathrm{SSF}}=12.416\right)$, contributing to a higher average effective population size to PMA $\left(\mathrm{Ne}_{\mathrm{PMA}}=4.629 \times 10^{16} ; \mathrm{Ne}_{\mathrm{SSF}}=8.496 \times 10^{3}\right)$. Theses results indicated that size (of the fragment) matters regarding migration. SSF is a conservation unit twice larger than PMA (not taking in account that SSF is surrounded by several other fragments of Araucaria forest in private properties, which must double or even triple the total size of the area, and PMA is surrounded by crop plantations and Guarapuava city limits) and this is probably driving the high rates of migrants between these areas (e.g., Schiffer et al., 2007). Moreover, the amount of migration detected is probably the main cause of the low genetic differentiation found for allozymes here, but other evolutionary forces, such as genetic drift and mutation rates, for example, must be in action to generate and maintain the differentiation detected for microsatellites. 
Table 1. Allozymes and microsatellites genetic variability parameters for two Drosophila maculifrons natural populations from Guarapuava/PR (Brazil).

\begin{tabular}{lcccccccc}
\hline \multicolumn{1}{c}{ Markers } & Populations $^{1}$ & $\mathbf{N}^{\mathbf{2}}$ & N.L. $^{\mathbf{3}}$ & $\mathbf{N . A .}^{\mathbf{4}}$ & $\mathbf{\%}_{(\mathbf{0 . 9 5})} \mathbf{5}^{\mathbf{3}}$ & $\mathbf{H . W .}^{\mathbf{6}}$ & $\mathbf{H o}^{\mathbf{7}}$ & $\mathbf{H e}^{\mathbf{8}}$ \\
\hline Allozymes & PMA & 51 & 8 & 3.00 & 37.5 & 66.7 & 0.1943 & 0.2933 \\
& SSF & 50 & 9 & 2.44 & 55.6 & 60.0 & 0.2538 & 0.2651 \\
\multirow{2}{*}{ Microsatellites } & PMA & 32 & 8 & 6.25 & 100 & 0 & 0.3994 & 0.7470 \\
& SSF & 41 & 9 & 7.78 & 100 & 11.1 & 0.3838 & 0.7444 \\
\hline
\end{tabular}

${ }^{1} \mathrm{PMA}=$ Parque Municipal das Araucárias, SSF = Parque Municipal São Francisco da Esperança; ${ }^{2}$ Sample size; ${ }^{3}$ Number of loci; ${ }^{4}$ Average number of alleles per loci; ${ }^{5}$ Proportion of polymorphic loci (more frequent allele not more than 95\%); ${ }^{6}$ Proportion of loci out of Hardy-Weinberg expectations among the polymorphic; ${ }^{7}$ Mean observed heterozygosity; ${ }^{8}$ Mean expected heterozygosity.

\section{Acknowledgements}

Funds were provided by CNPq (RP Mateus, grant number 479719/2011-0), SETI/Fundação Araucária (R. P. Mateus, grant number 868/2012); CAPES (DC Silva Master's Fellowship); FINEP; and UNICENTRO.

\section{References}

BEERLI, P., 2012. MIGRATE documentation (version 3.2.1). Technical Report. Available from: <http://popgen.sc.fsu.edu>. Access in: 28 Apr. 2014.

CAVASINI, R., BUSCHINI, MLT., MACHADO, LPB. and MATEUS, RP., 2014. Comparison of Drosophilidae (Diptera) assemblages from two highland Araucaria Forest fragments, with and without environmental conservation policies. Brazilian Journal of Biology, vol. 74, no. 4.

CENZI DE RÉ, FC., GUSTANI, EC., OLIVEIRA, APF., MACHADO, LPB., MATEUS, RP., LORETO, ELS. and ROBE, LJ., 2014. Brazilian populations of Drosophila maculifrons (Diptera, Drosophilidae): low diversity levels and signals of a population expansion after the Last Glacial Maximum. Biological Journal of the Linnean Society. Linnean Society of London, vol. 112, no. 1, p. 55-66. http://dx.doi.org/10.1111/bij.12244.

HEINZ, NP., 2012. Variabilidade molecular sazonal de Drosophila mediopunctata (Diptera: Drosophilidae). Guarapuava: UNICENTRO. Dissertação de Mestrado.

LABORDA, PR., KLACZKO, LB. and SOUZA, AP., 2009. Drosophila mediopunctata microsatellites. II: Cross- species amplification in the tripunctata group and other Drosophila species. Conservation Genetics Resources, vol. 1, no. 1, p. 281296. http://dx.doi.org/10.1007/s12686-009-9069-9.

MACHADO, LPB., SILVA, DC., SIMÃO, DP. and MATEUS, RP. 2012. Spatial variation of genetic diversity in Drosophila species from two different South America environments. In CALISKAN, M. Genetic variation in animals. Rijeka: Intech. p. 45-62.. http:// dx.doi.org/10.5772/32971.

MATA, RA., MCGEOCH, M. and TIDON, R., 2010. Drosophilids (Insecta, Diptera) as Tools for Conservation Biology. Natureza \& Conservação, vol. 8, no. 1, p. 60-65. http://dx.doi.org/10.4322/ natcon.00801009.

MATEUS, RP. and SENE, FM., 2003. Temporal and spatial allozyme variation in the South American cactophilic Drosophila antonietae (Diptera; Drosophilidae). Biochemical Genetics, vol. 41, no. 7-8, p. 219-233. http://dx.doi.org/10.1023/A:1025506301239. PMid:14587665

SAAVEDRA, CCR., VALENTE, VLS. and NAPP, M., 1995. An ecological/genetic approach to the study of enzymatic polymorphisms in Drosophila maculifrons. Brazilian Journal of Genetics, vol. 18, no. 2, p. 147-164.

SCHIFFER, M., KENNINGTON, WJ., HOFFMANN, AA. and BLACKET, MJ., 2007. Lack of genetic structure among ecologically adapted populations of an Australian rainforest Drosophila species as indicated by microsatellite markers and mitochondrial DNA sequences. Molecular Ecology, vol. 16, no. 8, p. 1687-1700. http:// dx.doi.org/10.1111/j.1365-294X.2006.03200.x. PMid:17402983

VOELKER, RA., SCHAFFER, HE. and MUKAI, T., 1980. Spontaneous allozyme mutations in Drosophila melanogaster: rate of occurrence and nature of the mutants. Genetics, vol. 94, no. 4, p. 961-968. PMid:17249027. 